\title{
Needs Analysis: E-Learning-Based of Intensive Reading with Moodle Application
}

\author{
Estika Satriani $^{1, *}$ M. Zaim ${ }^{1}$ Ermanto $^{1}$ \\ ${ }^{1}$ Universitas Negeri Padang \\ *Corresponding Author. Email: satrianiestika06@gmail.com
}

\begin{abstract}
The current intensive reading instruction is predominantly teacher-controlled and textbook-bound, finding it challenging for students to take develop of their own learning and to find learning opportunities to practice. Moodle e-learning as one of the selected learning management system will be used to solve these learning problems. This study aims to evidently identify major gaps and the needs of Moodle elearning by the students and lecturer in learning process of intensive reading class. Descriptive method with survey technique was used in this study. In collecting the data, questionnaire distributed for seventyeight students and interviewed five reading lecturers. The result of analysis data revealed that ninety percent of learners need the changes of learning proses of intensive reading by using the smart media such e-learning Moodle, and all of reading lecturers gave positive responds to implement an e-learning to improve their teaching experience. Findings in the present study could be provided as implications for course designers and recommendations for future studies.
\end{abstract}

\section{Keywords: Learning Intensive Reading, Need Analysis, e-Learning Moodle}

\section{INTRODUCTION}

Intensive Reading plays a crucial part in the eventual result of English instruction at a college level for English majors as a core subject. Intensive reading learning process is designed to be a foundation for new students to become independent readers who are able to make wise decisions in choosing reading materials that really answer their curiosity. Learning focus of intensive reading includes learning vocabulary and grammar, ideas such as themes and topics, new skills such as making conclusions and identifying main ideas, recognizing text types, and paying attention to text features such as genre structure and cohesion [1]. Besides that, one of intensive reading characteristics is learn only in the classroom with the material is assigned up by the lecturer. The demand of integration technology into learning process has changed the current learning style and learning situation. Therefore, the teachers need to develop the design of learning process based on the students need.

A learning design must consider the main objectives of learning and activities carried out into measurable and efficient behavior. In designing a learning process with the help of technology, its characteristics must be modeled correctly. The learning process should have the potential to develop an independent learning atmosphere, attract the attention of students by taking advantages of the momentum technological progress, especially information and communication technology
[2]. Introducing of technological products can be used in education proses with the intention of develop the educators competences through the teaching and learning process, such as media based on the internet, to increase the quality of education. Educators strongly hold that it is greatly important and necessary to apply multimedia in College English teaching. In the new era, with the rapid development of science and technology, learning with internet and web based has become two indispensable skills. The College English Curriculum Requirements issued by Ministry of Education proposed using the internet as a medium to be better English teaching and learning process in college.

Various types of sophisticated media used in supporting the learning process, one of the learning media that is expected to create an attractive and conducive learning atmosphere is the use of multimedia e-learning with Moodle application. E-learning is online learning that functions as information and communication system, as well as a medium in implementing the learning process [3].

The Moodle-based College English instruction can compensate for the deficiency of the traditional way, integrating the multimedia, network, and English, with the teacher as the guider and the student as the center. Elearning with the Moodle applications presents important features where users can develop their learning process inside and outside the classroom. Elearning here, besides having a role to complement face- 
to-face classes, can also replace scheduled classes with learning outside the classroom or distance. The learning method with Moodle can use synchronous (online learning, conferencing, forums) and asynchronous (learning by chatting, messaging, and email), teaching materials use features (text, e-books, files, folders, URLs, images, videos, etc), the assessment uses (assignment, quiz, feedback, choice, survey, questionnaire), and to follow the progress of the learning process of students by using (completion tracking)[4].

Based on the explanation above, the researcher intends to reveal the analysis of the needs for development of elearning-based of intensive reading with Moodle application. Furthermore, [5] stated several considerations when carrying out a needs analysis. First, needs analysis directly targets the objectives and content of the material or the subject of learning. Second, needs analysis is needed to reveal what students already know and what students need to know. Then a need analysis is required to create a belief that design of learning with elearning and material contain is useful, relevant and helpful for students. Therefore, in this study, need analysis is the preliminary phase to develop, analyze, assess, and evaluate intensive reading class and answer the question are students and lecturers need an intensive reading learning process with e-learning?

\subsection{Related Work}

\subsubsection{Need Analysis}

Some experts give a different meaning for needs analysis words. One of expert (1920s) from India came up with the idea about "the need" to cover what students need to do in the situation they want to reach in learning a foreign language and how learners should become more proficient at the language during the study period [6]. [7] stated that need analysis discuss about needs, desires and shortcomings. [8] assert it as the discrepancy between what actually students' needs and what should be the students learn. The analysis is basically viewed as a development of communication assessment, what needs to be done by the students on target language. [9] considers the needs analysis most important to make plan of language courses in English language curriculum. However, Needs Analysis conducted for the purpose of evaluating learners' and teachers' attitudes, opinions and beliefs towards a proposed or intended change or innovation should have the following frame work [10].

A learning system that is not appropriate to the learners ' needs does not contribute to a positive learning experience, because encouragement and inspiration also have an impact on learning. Therefore, learning environments that do not fulfill learners' expectations will de-motivate learners. At all stages of the implementation of an education system, Needs Analysis can play a critical role as it provides a tool for evaluating the needs, and steps can be taken to address them and thereby preserve commitment by adding significance and providing more potency to learning experience. Needs analysis discovers and describes language needs by using an analysis of a linguistic practice which characterizes the target situation within a discourse community. When the curriculum content, materials, and teaching approaches match learners' perceived and actual needs, learners' motivation and success are enhanced [11].

\subsubsection{Components of Intensive reading learning Needs Analysis}

Study of Intensive Reading Course needs may be categorized as Target Situation Analysis (TSA), Learning Situation Analysis (LSA), Present Situation Analysis (PSA), and Mean Analysis (MA). These aspects are important components for determining the needs of learners in the learning process [6]. It focuses on defining the learning process needs of the learners in university.

TSA procedures start from design to determine the implementation of intensive reading course need until the end of learning [9]. [12] assert that a needs study that reflects on the needs of students at the end of a language course can be considered a TSA (Target Situation Analysis). In addition, TSA is defined as the activities of learners to learn English for the target situation. TSA includes objective, perceived and product-oriented needs. The objective and perceived needs are derived by outsiders from facts, from what is known and can be verified. Therefore, to spell English words correctly, it is an objective/perceived need. Product-oriented needs are derived from the goal or target situation [10]. Learning Situation Analysis (LSA), Effective ways of learning skills and language is related to subjective, sense and process-oriented needs [10]. [10] Present Situation Analysis (PSA) evaluated strengths and weaknesses in the experience of language skills and learning of language. Means Analysis aimed at the setting in which a course will be conducted or the setting in which a design will take hold, sufficient condition and sustain [10].

\subsubsection{Studies on Needs Analysis}

Many previous study conducted by the researches on needs analysis in Intensive reading class. The findings from need analysis reported by [13], it is very important to include language learning strategies into language courses to provide greater opportunities for learners to make language learning an autonomous process. The next researcher notify the result of analysis research, "the translation method and lecturing method, often adopted in the advanced IR teaching, are rather ineffective and, in the final analysis, a way of cramming" [14]. In line [15] stated that teachers can assist students in applying strategies that are in accordance with language learning activities so that these strategies can be used independently in new activities. Further, [16] criticized the learning strategy of Intensive reading. According to them, intensive reading 
strategies are irrelevant and ineffective with current learning. They stated that exercise and preparation the students to learn independently is an effective for intensive reading strategies. Related with need analysis of learning reading, the result of [17] research, he proposed the developing of learning material should be made relevant to students experiences, background, target needs (outside the classroom), and affective needs. Others research has given the result, learning Intensive reading, needed to develop by both teachers and students with changing their stereotyped idea from traditional learning to interactive learning[18]. [19] did the needs analysis for Business English curriculum design.

Based on the literature above, it can be known that some studies were done on needs analysis for learning reading course for college students. Of the several needs analyzes conducted on reading learning, no one has conducted a needs analysis for the development of an intensive reading learning process. This study probed the needs of English Language Education Students at the first semester in learning of Intensive Reading course. The present study was designed to answer the following research questions: 1) how is the learning process needed in the intensive reading class? 2) What are interview responses from English-lecturers on the needs of learning process in intensive reading class?

\section{METHOD}

The data of this research obtained from the questionnaire distributed for the students and structured interview for lecturers. It can be seen in the following description:

\subsection{Questionnaire.}

The questionnaire as instrument used in this study to get the responses from the first semester students and reading lecturer of English Language Education of Universitas Islam Riau. The instrument was revised and validated by two experts. The questionnaire included two parts: background and learning process needs, total 32 statements. Part one: background included personal information (name, age and field of study, and direction) learning need score based on a five-liker scale 1) strongly agree, 2) agree, 3) natural, 4) disagree, and 5) strongly disagree). Part two: learning process needs included (1) Target Situation Analysis (statement 1-9) on learning process intensive reading needs (objective need, perceived need, and product-oriented need), (2) Learning Situation Analysis (statements 10 - 17) on learning activities need (subjective need, felt need, and process oriented need), (3) Present Situation Analysis (statement 18 - 24) on learning of reading skill (strength and weaknesses in language, skill, learning experiences), (4) lecturer responses (question 1-10), lecturer teaching need. Then, the results of students' responses through giving questionnaire are interpreted into four categories of needs; (1) Not needed, (2) Rather needed, (3) Needed, (4) Very needed.

The questionnaires were distributed for seventy-eight students. Then, participants were given 30 minutes to provide the responses by giving checklist in the questionnaire. After that the questionnaire collected by the researcher to be analyzed. The questionnaire data were analyzed by looking for the percentage of students' answers based on the question items in the questionnaire, and then calculated the average score of student needs. The result of mean score then interpreted into the need interval score.

Table 1. Need Categories of Students responses on E-learning -based

\begin{tabular}{|l|c|l|l|}
\hline No & Average of Needs Crateria & Category of Needs Crateria & Note \\
\hline 1 & $1.0-1,4$ & Not Needed & Not a priority \\
\hline 2 & $1.5-2.0$ & Rather Needed & Not a priority \\
\hline 3 & $2.1-2.9$ & Needed & Priority \\
\hline 4 & $3.0-4.0$ & Very Needed & Priority \\
\hline
\end{tabular}

[20]

Recapitulation of students' responses for learning process of Intensive Reading Need can be seen in the following table:

Table 2. Recapitulation of students' responses for learning process of Intensive Reading Needed

\begin{tabular}{|c|l|c|c|c|}
\hline No Item & Requirement Criteria on the statements & $\begin{array}{c}\text { Score in } \\
\%\end{array}$ & $\begin{array}{c}\text { Mean } \\
\text { Score }\end{array}$ & Categories \\
\hline 1 & $\begin{array}{l}\text { Intensive reading learning is presented through the online } \\
\text { learning process / e-learning.(Moodle) }\end{array}$ & $\mathbf{8 7 . 5}$ & $\mathbf{3 . 5}$ & Very needed \\
\hline 2 & $\begin{array}{l}\text { Intensive reading learning needs to do without space bound } \\
\text { and specified time }\end{array}$ & $\mathbf{9 0}$ & $\mathbf{3 . 6}$ & Very needed \\
\hline 3 & $\begin{array}{l}\text { Interaction of intensive reading learning in group } \\
\text { discussions, question and answer between students and } \\
\text { lecturers, students and students through e-learning (Moodle) }\end{array}$ & $\mathbf{9 2 . 5}$ & $\mathbf{3 . 7}$ & Very needed \\
\hline 4 & $\begin{array}{l}\text { Learning material of intensive reading is given in online / e- } \\
\text { learning (Moodle) }\end{array}$ & $\mathbf{8 5}$ & $\mathbf{3 . 4}$ & Very needed \\
\hline
\end{tabular}




\begin{tabular}{|c|l|c|c|c|}
\hline 5 & $\begin{array}{l}\text { Sources of learning material from (modules, E-books, URLs, } \\
\text { videos, slides, etc.) }\end{array}$ & $\mathbf{9 0}$ & $\mathbf{3 . 6}$ & Very Needed \\
\hline 6 & $\begin{array}{l}\text { Assignments given by lecturers via online / e-learning } \\
\text { (Moodle) }\end{array}$ & $\mathbf{9 2 . 5}$ & $\mathbf{3 . 7}$ & Very Needed \\
\hline 7 & Using digital documents rather than hardcopy & $\mathbf{9 2 . 5}$ & $\mathbf{3 . 7}$ & Very Needed \\
\hline 8 & Computer skills (typing, creating, storing files, etc.) & $\mathbf{8 7 . 5}$ & $\mathbf{3 . 5}$ & Very needed \\
\hline 9 & $\begin{array}{l}\text { Internet skills (accessing the internet, downloading, storing, } \\
\text { opening and sending email, editing files, etc.) }\end{array}$ & $\mathbf{9 2 . 5}$ & $\mathbf{3 . 7}$ & Very needed \\
\hline 10 & $\begin{array}{l}\text { Supporting campus infrastructure for learning with } \\
\text { e-learning (internet access, server, and computer lab) }\end{array}$ & $\mathbf{8 5}$ & $\mathbf{3 . 4}$ & Very needed \\
\hline & \begin{tabular}{l} 
Total \\
\hline
\end{tabular}
\end{tabular}

The data in the table 4.1 above is the result of recapitulation of student responses to the questions in the questionnaire. The questionnaire data were analyzed and classified based on the student's needs for the learning process required by students. From 32 required statements, ten statements were categorized as statements of student needs. These categories based on the mean score of students responses. Students need to learn Intensive Reading by using e-learning or $87.5 \%$ students agree with this statement. The other students need is learning can be done anytime and anywhere. $90 \%$ students agree with this statement. Further category of students need is interaction between students and lectures can be done by e-learning. $92.5 \%$ students agree with this statement. Beside, category learning material given by e-learning is also needed by the students, $85 \%$ students agree with the statements.

Related to learning materials, students need many learning resources include modules, E-books, URLs, videos, slides, etc. $90 \%$ students agree with this statement. Assignments are given by lecturers via online / e-learning is one of students need in learning activities of intensive reading. $92.5 \%$ students agree with this statement. Statement of using digital documents rather than hardcopy is also needed by students. $92.5 \%$ students agree with this statement. Students need the skill to operate the computer because it is the basic skill the students must have to learn with e-learning. $87.5 \%$ students agree with this statement. Furthermore, learning with e-learning demands students have internet skill to help them in learning activities. $92.5 \%$ students agree with this statement. Supporting campus infrastructure for learning with e-learning (eg. internet access, server, and computer lab) needed by the students. $85 \%$ students agree with this statement. Total score in the table indicated that $90 \%$ students agree with the intensive reading learning process with e-learning Moodle. Mean score 3.6 is needed category.

\section{RESULTS AND DISCUSSION}

2.1.2 Interview data from English-lecturers on the needs of learning process of intensive reading class

Interview was held for the five of reading lecturers on Mei 12, 2020. The question of interview are (1) What obstacles were you faced during the learning process of intensive reading class?, (2) How do you solve that problems ? (3) What do you think learning of intensive reading by e-learning-based?, (4) do you think elearning can give solution in learning problems?, why?, (5) Where can play e-Learning role during the learning process?

The answer of questions number 1, all of lecturers have problems in limited allocation of time for learning in the class. They said that, they lack of time in completing learning material in the class. They need additional classes to achieve learning objectives. The answer of the question number 2 , lecturer 1 and 3 said that they asked the students to get the additional class. Meanwhile lecturers 2,4,5, they said, to complete their learning process, they gave the students task. The answers the question number 3, all lecturers agree that intensive reading learning is presented with e-learning. The question number 4 , all lecturers answered, they believed e-learning could help to solve the problems in the learning process, because many all lecturers answered that they believed e-learning could help solve problems in the learning process, because e-learning was able to cover all obstacles and shortcomings that existed in the learning process. For the last questions, all lecturers answer that question, e-learning can be used in presenting learning material, discussing of learning, accessing learning resources, giving assignments, and many others.

Intensive reading learning for years have been emphasized in teacher-dominated classrooms, learning only depends on what the teacher provides, students do not play an active role in learning process. In intensive reading courses, the teacher traces each text linearly, word by word, and sentence by sentence so that students can understand everything about the text in terms of grammar structure, usage, vocabulary, and sentence comprehension. This learning model is no longer suitable for students who tend to interact via the internet 
or digital media. For that, it is necessary to change the learning process according to the character of today's students.

Based on the results of the data analysis described above, it can be seen that there are gaps in the current learning process with the demands and desires of changing the learning process in accordance with the conditions and character of students in this digital era. In line with [21], she said that in this era of technology, the digital revolution has transformed almost everything include Education sector. Most of the teaching and learning processes in the classrooms these days are changing from autocratic style to democratic or participatory style where learners play an active role. This need is reflected in the results of observations as a preliminary disclosure of problems and the results of analysis of student questionnaire statements and interviews conducted with lecturers. The change in the learning process that students and lecturers want is the presentation of a complete and systematic learning process using learning media that is attractive, modern and able to motivate student learning and can be accessed by students anywhere and anytime they need. This learning model is expected to solve problems in learning that are happening today.

Besides, the results of in-depth interviews with the lecturers who hold intensive reading subjects show that there are several obstacles in the learning process, that are students having difficulty understanding the learning material. This difficulty was triggered because of lack explanation in detail given by the lecturer due to the limitations of the media used. The media used by the lecturer learning is too monotonous so it doesn't attract the students to pay attention in learning. Besides that, limited time also become the problem both the lecturer and students. They could not complete their learning process in the classroom, they need to additional time to achieve learning objective. In line with [22], he stated that the teachers' role, learning methods and strategies are vital, also the use of authentic materials, interactive media, motivate learners to develop their linguistics and communicative competence.

The result of this study leads to the use of e-learning in overcoming obstacles and problems in the learning process. Lecturers and students think that e-learning can help to wage the learning process and also increase knowledge in the use of learning technology. It is also easy to connect anywhere anytime.

\section{CONCLUSION}

The result of need analysis for e-learning-based intensive reading learning is based on four main needs. First, the need for learning media that is attractive, modern and able to motivate student learning. Second, the need for distance learning that can be done anywhere and anytime. Third, students need for many learning resources. Fourth, the need develop of knowledge in the use of technology for both students and lecturers. Findings in the present study could be provided as implications for course designers and recommendations for future studies.

\section{REFERENCES}

[1] J. Macalister, "Today's teaching, tomorrow's text: Exploring the teaching of reading," ELT J., vol. 65, no. 2, pp. 161-169, 2011.

[2] M. Lytras, M. Angel Sicilia, and A. Naeve, "Learning processes and processing learning: From organizational needs to learning designs," J. Knowl. Manag., vol. 12, no. 6, pp. 5-14, 2008, doi: 10.1108/13673270810913586.

[3] O. Oludare Jethro, A. Moradeke Grace, and A. Kolawole Thomas, "E-Learning and Its Effects on Teaching and Learning in a Global Age," Int. J. Acad. Res. Bus. Soc. Sci., vol. 2, no. 1, pp. 2222-6990, 2012.

[4] K. Jebari, F. Boussedra, and A. Ettouhami, "Teaching 'information systems management' with moodle," Int. J. Emerg. Technol. Learn., vol. 12, no. 4, pp. 4-16, 2017, doi: 10.3991/ijet.v12i04.6183.

[5] I. S. P. Nation and Macalister. J, Language Curriculum Design. New York \& London: : Routledge, 2010.

[6] M. Rahman, "English for Specific Purposes (ESP): A Holistic Review," Univers. J. Educ. Res., vol. 3, no. 1, pp. 24-31, 2015, doi: 10.13189/ujer.2015.030104.

[7] A. Hutchinson, T., \& Waters, English for Specific Purposes. Cambridge: : Cambridge University Press., 1987.

[8] G. Brindley, The Role of Needs Analysis in Adult ESL Programme Design:The Second Language Curriculum, In R. John. Cambridge: Cambridge University Press., 1989.

[9] R. West, "Needs analysis in language teaching," Lang. Teach., vol. 27, no. 1, pp. 1-19, 1994, doi: $10.1017 / \mathrm{S} 0261444800007527$.

[10] M. J. Dudley-Evans, T., \& ST John, Developments in English for Specific Purposes. Cambridge: Cambridge University Press, 1998.

[11] L. T. Pushpanathan and A. Professor, "A Need For Needs Analysis," Int. J. Appl. Res. Int. J. Appl. Res. Stud. ISSN, vol. II, no. I, pp. 22789480, 2013.

[12] P. Robinson, ESP Today: A Practitioner's Guide. New York: Prentice Hall., 1991.

[13] R. A. Hashim and S. A. Syed Sahil, "Examining Learners' Language Learning Strategies," RELC J., vol. 25, no. 2, pp. 1-20, 1994, doi: $10.1177 / 003368829402500201$.

[14] J. Xiao, "Some Thoughts on the Teaching of Intensive Reading at Advanced Level," Foreign Lang. Teach. Res., vol. 58, no. 4, p. 37, 2004.

[15] J. Hu, "Evaluating Autonomous Foreign Language Learning Capacity," J. Foreign Lang. World, vol. 4, no. 145, pp. 12-17, 2011.

[16] Wang - Yang, "Problems and Strategies in 
Learning to Write a Thesis Proposal: A Study of Six M.A. Students in a TEFL Program,' Chinese J. Appl. Linguist., vol. 35, no. 3, p. 324, 2012.

[17] K. Graves, Designing Language Course: A Guide for Teachers. Boston: Heinle and Heinle Thomson Learning, 2000.

[18] W. Ji, "Analysis of Issues on the Part of Teachers in College English Intensive Reading Class," J. Lang. Teach. Res., vol. 1, no. 4, pp. 515-518, 2010, doi: 10.4304/j1tr.1.4.515-518.

[19] J. Li, "Needs Analysis of Business English Undergraduates and the Implications to Business English Curriculum Design," $A d v$.
Lang. Lit. Stud., vol. 5, no. 4, pp. 33-37, 2014.

[20] D. Fitriani, Y. RASYID, and R. DEWANTI, "Need Analysis on Developing Essay Teaching Material base on Brainwriting Strategy," Int. $e$ Journal Educ. Stud., vol. 4, no. 7, pp. 81-92, 2019, doi: 10.31458/iejes.608018.

[21] M. Sharma, "Teacher in a Digital Era," Glob. J. Comput. Sci. Technol., vol. 17, no. 3, pp. 1114, 2017.

[22] M. H. Mohammed, "Challenges of Learning English As a Foreign Language ( Efl ) By NonNative Learners," Int. J. Soc. Sci. Econ. Res., vol. 3, no. 04, pp. 1380-1400, 2018, [Online]. Available: www.ijsser.org. 